\title{
Social Responsibilities and Evaluation Indicators of Listed Companies in the Perspective of Interest Groups*
}

\author{
Shuhua Liu ${ }^{1}$, Li Cai ${ }^{1}$, Zhi Li ${ }^{2}$ \\ ${ }^{1}$ International Business School, Dalian Nationalities University, Dalian, China; ${ }^{2}$ Vocational and Technical School, Inner Mongolia \\ Finance and Economics College, Hohhot, China. \\ Email: lshh622@126.com, caili@dlnu.edu.cn, liccheng@hotmail.com
}

Received April 27 ${ }^{\text {th }}, 2012$; revised May $4^{\text {th }}, 2012$; accepted June $14^{\text {th }}, 2012$

\begin{abstract}
With advocating scientific outlook on development and building a harmonious society, China has paid more and more attention to corporate social responsibilities, which mean that companies should fulfill their duties for the interest groups, such as shareholders, employees, consumers, suppliers, communities and governments. As China's major economic entities, listed companies are supposed to be the pioneers who undertake on social responsibilities. From the standpoints of interest groups, it is necessary to define and determine the social responsibilities of listed companies, build an evaluation indicator system for their responsibilities, turn their responsibilities from the invisible into the visible and explore evaluation modes as well as scientific methods to evaluate their performance, so as to guide them to perform their social responsibilities properly.
\end{abstract}

Keywords: Listed Companies; Social Responsibility; Interest Group; Evaluation Indicator

\section{Introduction}

From a global perspective, it has been an inevitable trend that corporations undertake social responsibilities, which are in the scope of laws and standard management rather than in the ethical scope. At the same time, social responsibilities have been the recognized indicators of judging leading companies as high standards and strict requirements. As China's major economic entities, listed companies should be the pioneers who undertake social responsibilities. Chinese government, academia and listed companies do need to face the "corporate social responsibilities"; based on the advanced concepts and practical experience of foreign companies, they should not only probe how listed companies perform their social responsibilities, but also explore scientific methods to evaluate their performance.

\section{Social Responsibilities of Listed Companies}

\subsection{Corporate Social Responsibilities Based on the Interest Groups}

The concept of "Corporate Social Responsibilities" originated in the United States and was proposed by Shelton in 1924. Since its appearing in western countries, it has

\footnotetext{
* This research is supported by Liaoning Province Social Science Planning Fund (L08DJY087).
}

been one of the important research topics in many subjects, such as economics, management, law and ethics. However, there has been no consensus on its definition yet.

Shelton connected corporate social responsibilities with the responsibilities that enterprises met the demand of internal and external human beings. Besides, he held the opinion that corporate social responsibilities were relevant to the moralities. Whereas, American economist Milton Friedman believed that corporate social responsebilities just meant the pursuit for profits. Stephen P. Ross thought that corporate social responsibilities were the obligations that enterprises should realize long-term goals which were conducive to the society rather than the obligation required by the law or the economy. Meanwhile, Harold Koontz and Heinz Weihrich adhered to the opinion that corporate social responsibilities indicated that enterprises should seriously consider the impact of their action on the society. Ricky W. Griffin insisted that corporate social responsibilities were to protect and improve the social welfare in the wake of the growth of profits [1].

Corporate social responsibilities also have various explanations in China. Some of scholars share the view that companies should not regard it as their only target that they strive to make profits or earn considerable money for shareholders, but they should increase all social interests in addition to shareholders' interests. Some other 
scholars think that corporate social responsibilities mean enterprises do some business for the interests of the majority people in the society, while not for profits.

We believe that corporate social responsibilities mean companies should fulfill their duties for the interest groups, such as shareholders, employees, consumers, suppliers, communities, governments in order to boost the synchronous development of enterprises and the society. Companies should perform social responsibilities in the approaches which are favorable to the sustainable development of the society; they should protect and increase the social welfare while raising their own economic interests.

\subsection{Social Responsibilities of Listed Companies}

Shenzhen Stock Exchange issued Guidelines on Social Responsibilities of Listed Companies in Shenzhen Stock Exchange on September 25, 2006. It required listed companies in Shenzhen Stock Exchange should actively execute their social responsibilities; their performance should be assessed regularly; they should disclose the reports about their corporate social responsibilities voluntarily. The Guidelines defined corporate social responsibilities as follows: listed companies should take the responsibilities for the comprehensive development of the state and the society, natural environment and resources, shareholders, creditors, employees, customers, consumers, suppliers, communities and other interest groups.

Shanghai Stock Exchange issued Circular on Strengthening Listed Companies’ Performance on Social Responsibilities and Releasing "Guidelines on Environmental Information Disclosure of Listed Companies in Shanghai Stock Exchange” on May 14, 2008. It pointed out that companies should not only emphasize the interests of their own and shareholders, but also pay attention to the common interests of all interest groups including employees, creditors, customers, consumers and communities; they should combine short-term benefits with longterm interests consciously, integrate self-development with the comprehensive and balanced development of the society, and try to surpass their business goals.

We think that corporate social responsibilities should cover the responsibilities for shareholders, creditors, employees, consumers, suppliers, communities and other interest groups, as shown in Table $\mathbf{1}$.

\section{Evaluation Indicator System for Social Responsibilities of Listed Companies}

Listed companies are basic elements of the social economy. The operation and development of listed companies are influenced and constrained by various factors. The framework of the evaluation indicator system for social responsibilities of listed companies can be built accord-

Table 1. Social responsibilities of listed companies.

\begin{tabular}{|c|c|}
\hline Interest Groups & Content \\
\hline Shareholders & $\begin{array}{l}\text { 1. Increasing shareholders’ returns } \\
\text { 2. Guaranteeing shareholders' interests and preventing insider trading on stocks and interests } \\
\text { 3. Disclosing information truly and timely }\end{array}$ \\
\hline Employees & $\begin{array}{l}\text { 1. Ensuring employees' rights in employment, career, remuneration, rest and vacation, safety, health, } \\
\text { vocational skills training, social insurance, social welfare, etc., according to the labor law } \\
\text { 2. Providing employees with channels and opportunities to participate in the management democratically, } \\
\text { and valuing their demand and suggestions }\end{array}$ \\
\hline Creditors & Good credit status and solvency \\
\hline Consumers & $\begin{array}{l}\text { 1. Providing consumers with safe and reliable products } \\
\text { 2. Respecting consumers' right to know and option } \\
\text { 3. Providing excellent after-sales services } \\
\text { 4. Restraining forcing up prices }\end{array}$ \\
\hline Suppliers & $\begin{array}{l}\text { 1. Compling with contracts } \\
\text { 2. Ensuring the legitimate interests of suppliers } \\
\text { 3. Guaranteeing the quality and safety of products }\end{array}$ \\
\hline Communities & $\begin{array}{l}\text { 1. Participating in community construction and public welfare activities } \\
\text { 2. Absorption of community employment } \\
\text { 3. Supporting community education, improving community economic development, protecting } \\
\text { community environment, etc. }\end{array}$ \\
\hline Governments & $\begin{array}{l}\text { Paying taxes according to the law and regulations, bearing other responsibilities and obligations required } \\
\text { by the governments, accepting the government intervention and supervision, operating without tax evasion }\end{array}$ \\
\hline Environmental Resources & $\begin{array}{l}\text { 1. Making proper use of resources } \\
\text { 2. Protecting environment, reducing environmental pollution, bearing responsibilities for the resources } \\
\text { they waste and the environmental pollution they create }\end{array}$ \\
\hline
\end{tabular}


ing to Guidelines on Social Responsibilities of Listed Companies in Shenzhen Stock Exchange, Circular on Strengthening Listed Companies' Performance on Social Responsibilities and Releasing "Guidelines on Environmental Information Disclosure of Listed Companies in Shanghai Stock Exchange" and the existing literatures [2-4].

As Table 2 shows, the evaluation system consists of three levels. The first-level indicators include social responsibilities of listed companies. We list second-level indicators under every first-level indicator. Moreover, we design third-level indicators under every second-level indicator to evaluate social responsibilities thoroughly according to the principle of comprehensiveness and importance.

Table 2. Evaluation indicator system for social responsibilities of listed companies.

\begin{tabular}{|c|c|c|}
\hline \multirow[t]{3}{*}{ The first-level indicators } & The second-level indicators & The third-level indicators \\
\hline & Safety and health & $\begin{array}{l}\text { Implementation of occupational health and safety system; } \\
\text { Job security facilities; } \\
\text { Workplace health facilities; } \\
\text { Staff accommodation conditions; } \\
\text { Occupational health and safety training. }\end{array}$ \\
\hline & Working time & $\begin{array}{l}\text { Monthly work overtime; } \\
\text { Statutory holidays; } \\
\text { Right to ask for leaves. }\end{array}$ \\
\hline \multirow[t]{3}{*}{ Responsibilities to employees } & Remuneration and welfare & $\begin{array}{l}\text { Minimum wage rules; } \\
\text { Timely payment of wages and allowances ; } \\
\text { Pay rise rate of employee; Subsidies for housing, } \\
\text { transportation, education, etc.; } \\
\text { Payment of social insurance. }\end{array}$ \\
\hline & Employee equality & $\begin{array}{l}\text { Employment discrimination; } \\
\text { Freedom of religion belief. }\end{array}$ \\
\hline & Career development & $\begin{array}{l}\text { Orientation training; } \\
\text { Career planning for in-service staff. }\end{array}$ \\
\hline \multirow[t]{2}{*}{ Responsibilities to shareholders } & Returns on investment & $\begin{array}{l}\text { Earnings per share; Capital maintenance and appreciation; } \\
\text { Cash flow/debt ratio; } \\
\text { Total return on assets; } \\
\text { Achieved interest. }\end{array}$ \\
\hline & $\begin{array}{l}\text { Dividends } \\
\text { Information disclosure }\end{array}$ & $\begin{array}{l}\text { Dividend payout ratio; Dividend growth rate. } \\
\text { Check of selective information disclosure. }\end{array}$ \\
\hline Responsibilities to consumers & $\begin{array}{l}\text { Products quality and safety } \\
\text { Product maintenance and after-sales services } \\
\text { Consumers’ right to know } \\
\text { Consumer complaint }\end{array}$ & $\begin{array}{l}\text { Product repair rate. } \\
\text { Customer satisfaction. } \\
\text { Cost performance of products. } \\
\text { Consumer complaint. }\end{array}$ \\
\hline Responsibilities to suppliers & $\begin{array}{l}\text { Abiding by with contracts } \\
\text { Fair trade } \\
\text { Standardized management }\end{array}$ & $\begin{array}{l}\text { Default. } \\
\text { Satisfaction of suppliers. } \\
\text { Business integrity. }\end{array}$ \\
\hline Responsibilities to communities & $\begin{array}{l}\text { Increasing employment opportunities } \\
\text { Public welfare contribution }\end{array}$ & $\begin{array}{l}\text { Employment rate. } \\
\text { Positive attitude. }\end{array}$ \\
\hline Resnonsibilities to anyernments & Taxes payment legally & Tax rate. \\
\hline Responisidinties to goveniminents & Social contribution & Social contribution; Social accumulation. \\
\hline Responsibilities to protect & Environment protection & Environmental protection investment; Donation income. \\
\hline environmental resources & Utilization of resources & Unit energy consumption of income. \\
\hline
\end{tabular}




\section{Explanation for the Evaluation Indicator System}

The evaluation indicator system is a multi-angle and multi-level system which consists of numerous interrelated and interdependent indicators. It aims to reflect the performance of listed companies' social responsibilities in details objectively. Nevertheless, in reality, the evaluation system can only just include limited indicators and the significance and functions of these indicators vary.

1) As for "responsibilities to employees", there are many second-level indicators, because the importance of the human capital has been widely recognized. "Responsibilities to employees" are the important content of social responsibilities and listed companies have to bear such responsibilities.

2) There are many second-level indicators under "responsibilities to consumers", because consumers have great impact on listed companies. The recognition of consumers is a premise for listed companies to gain profits. Therefore, it is wise for listed companies to undertake their responsibilities to consumers.

3) Suppliers require listed companies to control product costs, improve operating efficiency and innovate new products and manufacturing processes. More and more companies have built strategic alliances with their suppliers now; however, the former must undertake their responsibilities to the latter so that they can maintain the sound long-term relationship with the latter and realize the win-win strategy based on the reciprocity.

4) Environmental resources are not physical interest groups, but they have been the key factors that affect the development of listed companies. Especially, as the lowcarbon economy has been introduced in the globalization development strategy, this evaluation indicator becomes more and more important.

5) Shareholders' interests are still the main goal for listed companies. ROE (Rate of Return on Common Stockholders' Equity) is the ratio of the net profit against the average net assets within a certain period. ROE reflects the profitability after investors invest their own capital and highlights the relationship between investment and return. Additionally, Capital Maintenance and Appreciation show the actual changes of the capital of companies in the current year. Return on Total Assets embodies the profitability of all assets of companies, corporate profitability and input-output. Three-year average capital growth rate reveals the capital accumulation of companies in three consecutive years, and it reflects the sustainable development degree and development trends of companies to a certain extent.

6) Indispensable supporters for the normal operation of companies include creditors, governments and communities. Listed companies have to coordinate with them and fulfill necessary responsibilities to seek the basis of the harmonious development.

\section{Advices on Strengthening Social Responsibilities of Listed Companies}

The governance and implementation of listed companies' social responsibilities can not achieve without a multilevel system which consists of the law, administrative intervention, economic regulation, social supervision, responsibility certification, listed companies' internal governance and voluntary self-regulation. The approaches of governance and implementation of listed companies' social responsibilities can be conducted in the following aspects.

\subsection{Governments Need to Actively Guide Listed Companies to Undertake the Social Responsibilities}

1) The government should strength the legal system, and actively guides listed companies to undertake social responsibilities voluntarily. The government may define social responsibilities of listed companies when amending the Company Law; the actual obligations of listed companies can be stipulated in other laws and regulations; the government may issue a series of preferential policies to encourage companies to undertake social responsibilities voluntarily. Besides, the government should define the scope of social responsibilities management, make guidelines on the disclosure of the information about social responsibilities. What's more, the government should establish a sound debt liability mechanism and creditor legal relief mechanism to strengthen the debt repayment obligations of shareholders and other insiders, and set up an impeccable system of corporate bankruptcy liquidation and reorganization to guarantee creditors' legitimate rights and interests.

2) The overall assessment on corporate social responsibilities ought to be strengthened by the government. The authorities need to advocate a new evaluation system to specify the assessment indicators for shareholders' responsibilities and social responsibilities. Guidelines for Constitution of Listed Companies, Corporate Governance Rules and Listing Rules may be amended to compulsorily require listed companies to disclose the information about their performance of social responsibilities, together with significant environmental and social risks.

3) The government should constitute the convention on listed companies' social responsibilities. Listed companies should comply with the provisions of the Company Law on employee participation; meanwhile, the convention on listed companies' social responsibilities should be established; the staff supervision and the development of listed companies should be stipulated. 
4) The government should build a complete information disclosure system on social responsibilities. The government's attitude determines the expectation of investors, and then investors may adjust their investment decisions. Therefore, supervisors should encourage companies to disclose information voluntarily and guide them how to disclose, in order to ensure reliability and validity of the disclosed information.

\subsection{Social Organizations Need to Play the Important Supervisory Roles}

In addition to the government, social organizations, such as environment protection organizations, consumer associations and trade unions, should play supervisory roles to make listed companies pay enough attention to social responsibilities and perform them driven by the public opinion and morality.

1) Improvement of social responsibilities disclosure mechanism. Sustainability Reporting Guidelines published by Global Reporting Initiatives covers drafting principles, content and specific indicators of social responsibility reports. It strives to achieve the comparability, reliability, rigor, timeliness and verifiability of the information disclosed in the reports. It provides us a good template and guidance. Meanwhile, Shenzhen Stock Exchange also encourages companies to prepare their reports according to it.

2) Enhancing the authenticity of social responsibility reports. The accuracy of the qualitative information depends largely on the clear and detailed expression, and the quantitative data should be noted with sources or proved. The issuance of the reports need be approved by the Stock Exchange, so we suggest that the Stock Exchange should require listed companies to provide sources or third-party confirmation for key financial data and non-financial data in the reports. The Stock Exchange may audit social responsibilities when the right time comes [5].

3) Technical specifications and support, covering report format, report points and content, third-party recognition. The audit system on the information about social responsibilities should be established as well as irregularities or frauds should be exposed to ensure the authenticity of the information, consolidate investors' confidence and improve the effectiveness of the information. In addition, investors should be trained to identify and analyze the information.

\subsection{Listed Companies Should Intensify the Awareness of Undertaking Social Responsibilities Initiatively}

The excellent fulfillment of social responsibilities mainly relies on the initiative of listed companies. They should not seek immediate interests, but also consider the harmonious relationship with the society or environment. They should bear social responsibilities to win the trust of the public, so that they will be bigger and stronger. Chinese listed companies should learn from large groups and large companies in the western developed countries, include social responsibilities into their development strategies and be more willing to assume social responsibilities.

1) Listed companies' awareness on social responsibilities can be strengthened by regulations and norms. The system and regulations of companies should reflect social responsibilities; rights, obligations and interests should be determined clearly; good performance should be praised and bad behaviors should be punished. The profound research on social responsibilities should be enhanced [6].

2) Listed companies should regard social responsibilities as principle goal in their operation. The operators of listed companies should be the major bearers of social responsibilities and shareholders should inspire them in reasonable ways. First, recompense according to the work. The wages of the operators should be consistent with their value at first; and then, they should be granted with additional recompense. Second, the operations should be granted with autonomy in management to ensure they have the ability to undertake social responsebilities initiatively. What listed companies do have a significant influence on the society. If they only focus on their development regardless of social responsibilities, they will damage the environment seriously, even their existence will be doubted by the society. Therefore, from the social perspective, listed companies should regard social responsibilities as principle goal in their operation, while they should consider profit maximization, earnings per share maximization or shareholders' wealth maximizetion as specific operating goals which are subordinate to the principle goal.

\section{Conclusion}

A company's social responsibilities reflect its ethics as well as its attitude towards life and the public. In a sense, its attitude toward social responsibilities and its performance determine its lifespan. On the other hand, under the premise of the sustainable development, the interests of employees and consumers will be guaranteed better, investors and creditors will acquire much more earnings, and communities will achieve more benefits. Only a company that experiences sustainable development will perform its social responsibilities more preferably.

\section{REFERENCES}

[1] M. E. Porter and M. R. Kramer, "The Link between Competitive Advantage and Corporate Social Responsibilities,” Harvard Business Review, No. 12, 2006, pp. 1-15. 
[2] H. Xu and X. X. Zhu, "Study on Social Responsibility Evaluation Indicator," Research on Economics and Management, No. 5, 2010, pp. 77-83.

[3] F. H. Yan and L. Zhao, "Construction of Evaluation Indicator for Performance of Corporate Social Responsibility,” Productivity Research, No. 2, 2009, pp. 146-148.

[4] S. Y. Yan, "On the Integrated Financial Evaluation on Listed Company’s Social Responsibilities,” Finance and
Economics, Vol. 229, No. 4, 2007, pp. 66-72.

[5] N. Yao, "Advice on Constructing Chinese Corporate Social Responsibility System,” Journal of Shanxi Finance and Economics University, Vol. 32, No. 1, 2010, pp. 115-132.

[6] S. Q. Gao, "Corporate Social Responsibilities and Governance Structure,” Xinhua Digest, No. 24, 2004, pp. 46-47. 